\title{
Growth of a Saccharomyces cerevisiae strain lacking hexose transporters in different sugars after transformation with a Scheffersomyces stipitis genomic library
}

\author{
Belisa Sales*, Davi Gonçalves, Bruna Scheid, Boris Stambuk \\ From 5th Congress of the Brazilian Biotechnology Society (SBBIOTEC) \\ Florianópolis, Brazil. 10-14 November 2013
}

\section{Background}

Brazil is the biggest ethanol producer in the world using sugarcane as substrate. From this process, bagasse is the main resulting by-product which can be used to produce second generation ethanol. Although Saccharomyces cerevisiae is the ideal yeast for the fermentative process, it cannot ferment xylose, one of the most abundant sugars in lignocellulosic biomass. Different yeast can ferment xylose, including S. stipitis [1], but not with the same efficiently rate as $S$. cerevisiae. Genes from xylose-fermenting yeasts can be used to genetically engineer S. cerevisiae to improve bioethanol production. Since it is widely known that the transport of sugars inside the cells is a limiting factor for the fermentation of sugars, and several reports have demonstrate that an increase in transport activity also increases the fermentative capacity of yeast cells [2], in the present work we have used a $S$. cerevisiae strain lacking hexose transporters (hxt-null) to screen a $S$. stipitis genomic library to identify putative xylose transporter genes.

\section{Methods}

The genomic library was constructed using DNA from S. stipitis by a private company (requested by Dr. Matsuhika from AIST, Japan) and the fragmented DNA was cloned into the overexpressing plasmid pPGK. These plasmids were used to transform a S. cerevisiaehxt-null strain (which can grow only in maltose) previously transformed with the integrative plasmid pAURXKXDHXR [3] that confers the cells the capacity to metabolize xylose. The clones were first select in solid

Universidade Federal de Santa Catarina, Florianópolis, Brazil synthetic medium with $2 \%$ xylose. Growth in microscale using synthetic medium with $2 \%$ maltose, xylose, glucose, fructose, galactose or mannose as carbon sources was performed using a Tecan Microplate reader (Tecan Echisto Infinite M200PRO) for up to $72 \mathrm{~h}$ at $28^{\circ}$ $\mathrm{C}$ under orbital agitation $(160 \mathrm{rpm})$. The absorbance was measured at $570 \mathrm{~nm}$ every 15 minutes.

\section{Results and conclusions}

Genomic libraries from different yeast on multi-copy plasmids can reveal potential genes [4] for the improvement of xylose transport in S. cerevisisae. We obtained $90 \mathrm{~S}$. cerevisiae transformants from the S. stipitis genomic library, and 8 clones were selected based on their capacity to grow on xylose and glucose synthetic medium, although the final absorbance in xylose was lower than when glucose was the carbon source (data not shown). Two transformants, BBY-D1Ss6 and BBYD1Ss90, grow higher than the other transformants in all the sugars tested, with a similar and marked growth in mannose. In contrast, BBY-D1Ss41 and BBY-D1Ss53 transformat strains did not grow on this sugar. The growth of strain BBY-D1Ss80 was also expressive in all sugars (mostly in glucose and fructose). In general, the eight transformants were able to grow on different sugars, not been specific to one carbohydrate neither specific for glucose only. We are analyzing the inserts present in the pPGK plasmid to verify which genes from the S. stipitis genome have been isolated in our work.

\section{Acknowledgements}

This work was funded by the Brazilian agencies CNPq, FAPESC and FINEP, and by the Japanese International Cooperation Agency (JICA). 


\section{References}

1. Jeffries TW, Grigoriev IV, Grimwood J, LaPlaza JM, Aerts A, Salamov A, Schmutz J, Lindquist E, Dehal P, Shapiro H, Jun YSU, Passoth V, Richardson PM: Genome sequence of the lignocellulose-bioconverting and xylose-fermenting yeast Pichia stipitis. Nature Biotechnol 2007, 25:319-326.

2. Stambuk BU, Eleutherio ECA, Florez-Pardo LM, Souto-Maior AM, Bon EPS: Brazilian potential for biomass ethanol: challenge of using hexose and pentose co-fermenting yeast strains. J Sci Ind Res 2008, 67:918-926.

3. Matsushika A, Watanabe S, Kodaki T, Makino K, Inoue H, Murakami K, Takimura O, Sawayama S: Expression of protein engineered NADP +-dependent xylitol dehydrogenase increase ethanol production from xylose in recombinant Saccharomyces cerevisiae. Appl Microbiol Biotechnol 2008, 81:243-255.

4. Hong ME, Lee KS, Yu BJ, Sung YJ, Park SM, Koo HM, Kweon DH, Park JC, Jin YS: Identification of gene targets eliciting improved alcohol tolerance in Saccharomyces cerevisiae through inverse metabolic engineering. J Biotechnol 2010, 149:52-59.

doi:10.1186/1753-6561-8-S4-P122

Cite this article as: Sales et al:: Growth of a Saccharomyces cerevisiae strain lacking hexose transporters in different sugars after transformation with a Scheffersomyces stipitis genomic library. BMC Proceedings 2014 8(Suppl 4):P122.

\section{Submit your next manuscript to BioMed Central and take full advantage of:}

- Convenient online submission

- Thorough peer review

- No space constraints or color figure charges

- Immediate publication on acceptance

- Inclusion in PubMed, CAS, Scopus and Google Scholar

- Research which is freely available for redistribution

Submit your manuscript at www.biomedcentral.com/submit 